\title{
Lust for life: coping with tuberculosis in late nineteenth- century Europe
}

\author{
Heini Hakosalo* \\ History of Sciences and Ideas, University of Oulu, P.O. Box 1000, 90014 Oulu, Finland \\ ${ }^{\star}$ Corresponding author. Email: heini.hakosalo@oulu.fi
}

\begin{abstract}
The paper uses the correspondence of three Finns - Elias Erkko, Henrik Erkko and Hilda Asp - to analyse the conceptual and practical means with which late nineteenth-century-educated Europeans coped with ill health in general and tuberculosis in particular. While the need to gain control over (the threat of) disease may well be universal, the specific coping methods are historical and context-specific. They are both conceptual and practical, both individual and collective. The paper focuses on the 1880s and 1890s, a period when tuberculosis provided an especially lucrative subsector of the booming European medical marketplace. Sanatorium treatment was still only one among many treatment options, and the theory of the bacterial causation of tuberculosis was far from being universally accepted. The paper charts the options available for people suffering from pulmonary tuberculosis and analyses the eclectic, sometimes idiosyncractic, ways that they combined elements from different conceptual scripts and therapeutic traditions.
\end{abstract}

Keywords: Consumption; Pulmonary tuberculosis; Disease conceptions; Medical marketplace; Illness experience; Late nineteenth-century Europe

This paper makes use of the correspondence of three individuals - Elias Erkko (1863-88), his fiancée Hilda Asp (1862-91) and his elder brother Henrik Erkko (1849-1906) ${ }^{1}$ - to study how late nineteenthcentury-educated Europeans coped with ill health in general and tuberculosis in particular. 'Coping methods', as perceived here, comprise both personals beliefs and collective conceptions and practices. They are largely conscious and active and, by definition, historically and culturally changing. The three historical actors were Finnish-speaking Finns ${ }^{2}$ and belonged to a network of artists and intellectuals that would consolidify into an influential nationalist group known as Nuori Suomi (Young Finland). The group played an important role in the turn-of-the-century national revival, and many of its members went on to hold powerful positions during the First Republic (1919-39). Not suprisingly, then, ErkkoAsp letters have been used as source material in quite a few historical and biographical studies focused on late-nineteenth- and early-twentieth-century Finland. ${ }^{3}$ As the journalist Marja Niiniluoto poetically puts

\footnotetext{
${ }^{1}$ For the sake of brevity and clarity, I mostly refer to Elias, Henrik and Hilda by their first names. In referring to their letters, Elias $=$ EE, Henrik $=$ HE and Hilda $=$ HA. Unless otherwise indicated, the letters are held by Päivälehden arkisto [The Päivälehti Archives] in Helsinki, Finland.

${ }^{2}$ At the time, the Grand Duchy of Finland was part of the Russian Empire. The majority of the people spoke Finnish as their first (and only) language, but Swedish was the language of the domestic elite and the dominant language of culture and higher education.

${ }^{3}$ Marja Niiniluoto, Hilda \& Elias. Hilda Aspin ja Elias Erkon kirjeenvaihtoa vuosilta 1884-88 (Helsinki: Helsingin Sanomat, 1983) focusses on the love story of Hilda Asp and Elias Erkko and is largely composed ot excerpts from their letters. The correspondence has been used as source material in Martti Jukola, Juhana Heikki Erkko. Elämä, runoilijatoiminta ja teokset. Kirjallisuushistoriallinen tutkimus I osa (vuoteen 1890) (Helsinki: University of Helsinki, 1930); Martti Jukola, Juhana Heikki Erkko. Elämä, runoilijatoiminta ja teokset. Kirjallisuushistoriallinen tutkimus II osa (vuodet 1890-1906) (Helsinki: Otava, 1939); Marjo Kuula (ed.), Sydämeen luettavaksi: J.H. Erkon elämäkerta (Tuusula: Tuusulan museo, 2018); Seppo Zetterberg, Eero Erkko (Helsinki: Otava, 2001); Minna Maijala, Herkkä, hellä, hehkuvainen. Minna Canth (Helsinki: Otava, 2014); Hanna Suutela, 
it in her book on Hilda Asp and Elias Erkko, 'The tone of the times hums through the initimate correspondence of the two lovers'. ${ }^{4}$

This paper relates to two strands of medical historiography: research on the late nineteenth century 'medical marketplace' and research on the history of tuberculosis. The term 'medical marketplace' has been used, notably in British historiography, to stress the pluralistic, competetive and poorly regulated character of medical markets and applied both in national and local contexts. ${ }^{5}$ During the latter part of the nineteenth century, the rise of the urban middle class created a intense demand for medical services, a demand that medical schools sought to meet by training an increasing number of professionals who then competed for patients, especially in major medical centres. Scarcity of centralised regulation and the therapeutic impotence of regular medicine left plenty of room for 'alterative' approaches and non-licensed healers. The century had seen some remarkable scientific advances but, while they had undermined the theoretical basis of traditional treatments, they had not generated effective new therapies. This paper looks at the bustling late nineteenth-century medical market from the point of view of 'customers' rather than providers and draws attention to the transnational character of the market.

Tuberculosis provided an especially lucrative sub-section of the medical market. It was an extremely common and usually chronic disease (or cluster of diseases) with a host of diffuse symptoms and an unpredictable course that left the road open for competing interpretations and made systematic testing of the efficacy of treatment methods particularly difficult. Medical authorities did not agree upon the etiology, let alone the best therapeutic practices. Two major changes took place in the understanding and treatment of tuberculosis during the latter part of the century. The first was the birth of the tuberculosis sanatorium. Görbersdorf, commonly regarded as the first modern, ie. specialised tuberculosis sanatorium, was opened in Silesia by Dr Hermann Brehmer (1826-89) in 1859. It was followed by a host of other high-altitude sanatoria for consumptives, first in German-speaking countries and then also elsewhere. ${ }^{6}$ Second, the German medical scientist Robert Koch (1843-1910) identified Mycobacterium tuberculosis as the cause of tuberculosis in 1882. ${ }^{7}$ The immense repercussions of Koch's discovery are obvious with hindsight: it established tuberculosis as a contagious rather than hereditary disease; it downplayed the role of environmental factors in the causation of the disease, and it confirmed the reconceptualisation of a host of pathological conditions that had so far usually been considered as separate diseases - such as consumption, scrofula, Pott's disease, lupus - as so many forms of tuberculosis. But, as medical historians have established, it took time for Koch's conception of

Impyet. Näyttelijättäret Suomalaisen Teatterin palveluksessa (Helsinki: Like, 2005); Antti Harmainen, "Kaikki voin kestää, voin elää, jos tiedän että hänet kerran vielä tapaan”. Spiritualismi ja teosofia sivistyneistön surutyön välineinä 1880-luvun lopulla', Historiallinen Aikakauskirja 112 (2014), 381-92.

${ }^{4}$ Niiniluoto, op. cit. (3), 13.

${ }^{5}$ The notion of 'medical marketplace' is discussed in Mark Jenner and Patrick Wallis, 'The medical marketplace', in Mark Jenner and Patrick Wallis (eds.), Medicine and the Market in Early Modern England and Its Colonies, c. 1450-c. 1850 (Basingstoke: Palgrave Macmillan, 2007), 1-2. Late nineteenth-century medical marketplace is examined eg. in Anne Digby, Making a Medical Living: Doctors and Patients in the English Market for Medicine, 1720-1911 (Cambridge: Cambridge University Press, 1994); Roy Porter, The Greatest Benefit to Mankind: A Medical History of Humanity from Antiquity to the Present (London: Harper Collins), 348-97 (ch. 12); David Peter Helm, 'Doctors, Druggists and Patients: The End of the Medical Marketplace in Mid-Nineteenth-Century Gloucester', Midland History 43, 1 (2018), 62-81; Heini Hakosalo, 'Freud \& Co. The mind at the medical market in Fin-de-Siècle Europe', in Niina Timosaari (ed.), Aatteiden ja oppien teillä. Juha Mannisen juhlakirja, Studia Historica Septentrionalia 73 (Rovaniemi: Pohjois-Suomen Historiallinen Yhdistys, 2014), $25-43$.

${ }^{6}$ For example. Anne Marie Châtelet, 'Early days of the sanatorium (1860-1902)', in Mia Hipeli and Esa Laaksonen (eds.), Alvar Aalto Architect: Paimio Sanatorium 1929-33 (Helsinki: Alvar Aalto Foundation \& Rakennustieto, 2014, 106-11); Richard Sievers, 'Herman Brehmerin 100-vuotismuisto', Tuberkuloosilehti 2, 3 (1926), 160-5.

${ }^{7}$ Robert Koch read his paper 'On the aetiology of tubercular disease' at the Berlin Physiological Society on 24 March 1882 and published it the next month. English reprint: Robert Koch, 'The etiology of tuberculosis (1882)', in K. Codell Carter (ed.), Essays of Robert Koch (Connecticut: Greenwood Press, 1987), 83-96. On Koch's discovery and its context, see Christoph Gradmann, Laboratory Disease: Robert Koch's Medical Bacteriology (Baltimore: The Johns Hopkins University Press, 2009). 
tuberculosis to be generally accepted. The reception was especially tardy in Britain. ${ }^{8}$ This paper looks at the process from the patient's point of view, highlighting the many uncertainties and competing options that faced the consumptive who navigated the European common market of medicine in the decade after Koch's discovery.

Historical research on tuberculosis is extensive but heavily focused on the twentieth century, when tuberculosis was recognised and fought as a major public health issue. ${ }^{9}$ In the nineteenth century, consumption was still seen as a problem for the individual and the family rather than the state. This is reflected in the nature of sources: reliable statistics, administrative sources and comprehesive surveys being scarce, studies on nineteenth-century tuberculosis are usually based on medical publications, literary texts and egodocuments. They tend to be qualitative and combine medical with cultural history. The image of the young, beautiful and sensual consumptive still looms large when the nineteenth century is discussed, forming a stark contrast with the policed, disciplined, hospitalised, medicated and often socially stigmatised twentieth-century tuberculotic. The nineteenth-century 'aesthetics of consumption', as expressed in art, literature and fashion, have been studied by Susan Sontag (1977) and by Clark Lawlor (2006), Catherine Byrne (2011), Carolyn Day (2017) and Alex Tankard (2018). The more recent research has added much detail and nuance to but not essentially undermined Sontag's contention that consumption was a disease particularly rich in cultural connotations and associations and subject to a high degree of aesthetisation and romantisation. ${ }^{10}$ In the case at hand, the romanticising script was only one of many and by no means the most prominent one.

The first part of the paper presents an outline of Elias and Henrik Erkko's and Hilda Asp's lives, with an emphasis on ill health; the second discusses the ways in which they sought to make sense of their illness (conceptual coping methods); and the third looks at their efforts to find effective treatment in the eclectic late nineteenth-century medical marketplace (practical coping methods).

\section{Living and dying with tuberculosis}

Henrik and Elias Erkko originated in a smallish farm in Central Finland. They lost their mother early, during the devastating 1886-8 famine. Their father was apparently not a great success either as a single parent or as a farmer. ${ }^{11}$ Despite their modest rural background, three of the five Erkko siblings left a

\footnotetext{
${ }^{8}$ On the reception of Koch's discovery, particularly in Britain, see F.B. Smith, The Retreat of Tuberculosis, 1850-1950 (London: Croom Helm, 1988), 36-8, 47-9; Michael Worboys, 'The sanatorium treatment for consumption in Britain, 18901914', in John V. Pickstone (ed.), Medical Innovations in Historical Perspective (New York: Palgrave MacMillan, 1992, 47-71), 49-50; Michael Worboys, 'From heredity to infection: tuberculosis, 1870-1890', in Jean-Paul Gaudillière and Ilana Löwy (eds.), Heredity and Infection: The History of Disease Transmission (London \& New York: Routledge, 2001), 81-99, 91-2.

${ }^{9}$ For an overview on the historiography of tuberculosis, see Linda Bryder, Flurin Condrau and Michael Worboys, 'Tuberculosis and its histories: then and now', in Flurin Condrau and Michael Worboys (eds.), Tuberculosis Then and Now: Perspectives on the History of an Infectious Disease (Montreal and Kingston: McGill-Queens University Press, 2010), 3-23.

${ }^{10}$ Susan Sontag, Illness as Metaphor (Harmondsworth: Penguin, 1983 [1977]); Clark Lawlor, Consumption and Literature: The Making of the Romantic Disease (Basingstoke: Palgrave Macmillan, 2006); Catherine Byrne, Tuberculosis and the Victorian Literary Imagination (Cambridge: CUP, 2011); Carolyn A. Day, Consumptive Chic: A History of Beauty, Fashion, and Disease (London: Bloomsbury, 2017); Alex Tankard, Tuberculosis and Disabled Identity in Nineteenth Century Literature: Invalid Lives (Cham: Palgrave Macmillan, 2018). Histories of tuberculosis that discuss also nineteenth-century developments include Sheila Rothman, Living in the Shadow of Death: Tuberculosis and the Social Experience of Illness in American History (Baltimore and London: The Johns Hopkins University Press, 1994); David S. Barnes, The Making of a Social Disease: Tuberculosis in Nineteenth-Century France (Berkeley: University of California Press, 1995); Katherine Ott, Fevered Lives: Tuberculosis in American Culture since 1870 (Cambridge, MA: Harvard University Press, 1996); Greta Jones, "Captain of All These Men of Death": The History of Tuberculosis in Nineteenth and Twentieth Century Ireland (Amsterdam: Rodopi, 2001); Helen Bynum, Spitting Blood: The History of Tuberculosis (Oxford: Oxford University Press, 2012). Finnish historical scholarship on tuberculosis focusses almost exclusively on the twentieth century. An exception is Mikko Jauho, Kansanterveysongelman synty. Tuberkuloosi ja terveyden hallinta Suomessa ennen toista maailmansotaa (Helsinki: Tutkijaliitto, 2007), a book that inquires into the emergence of anti-tuberculosis policies in the late nineteenth and early twentieth centuries.

${ }^{11}$ J.H. Erkko, 'Alkulause. Elias Erkko 12/4 1863-21/11 1888', in Elias Erkko, Elinan surma ynnä muita kirjoituksia (Helsinki: Eero Erkko, 1901), I-VIII; Jukola, op. cit. (note 3) I: 21, 45. The five siblings, including the less well known Kustaa and Hilda, are discussed in Antti Blåfield, 'Eerakkalan sisarukset kuohuvassa ajassaan', in Kuula, op. cit. (note 3), 290-317.
} 
significant mark on Finnish cultural and political history. Henrik was trained as a primary school teacher but made himself a name as a poet and playwrite. Eero (1860-1927) became a journalist, politician and the publisher and principal owner of what is still the largest and most influential newspaper in Finland. ${ }^{12}$ Much was expected of Elias, too. By the time of his death, he had not yet graduated from university but had established a reputation as a critic, translator and promising author. His main literary undertaking, a play called Elinan surma [The Slayer of Elina] was published only after his death ${ }^{13}$.

Henrik, the first born, was something of a surrogate father to Elias, who was the youngest. Henrik can be seen as a representative of what the historian Leonora Davidoff has called 'the intermediate generation' and identified as a characteristic feature of the large nineteenth-century family. ${ }^{14}$ As the first educated member of the family, he was also Elias's most important supporter and mentor during the 'class trip' that took the latter first to grammar school (1875) and then to university (1882) and, by the same token, from the peasantry to the educated classes. Elias's first dated letters to Henrik are from 1874, when the former was 11 years and had started grammar school in the town of Jyväskylä. ${ }^{15}$ Ill health became a dominant theme during the school year 1879-80, when Elias lodged with his sister's family in rather poor conditions. He described his ailments to Henrik in detail. He was badly constipated, which made 'blood rise to the head' and caused 'swelling under the heart'. He suffered from sleeplessness and mood swings, and his nerves were on edge. Sometimes, he was afraid he would go mad or die, and he grew tired and depressed. Henrik took Elias's problems to heart, showered him with moral and practical advice and took him out of the school for a year to give him time to recuperate. ${ }^{16}$ Elias passed the allimportant matriculation examination in spring 1882 and enrolled at the Imperial Alexander's University (a.k.a. the University of Helsinki) with a broad study plan that included classical languages, Finnish, aesthetics and philosophy. Ill health still figured in his letters but no longer dominated them. His health problems were much the same as before: recurrent catarrhs, occasional insomnia, indigestion and constipation, headaches, fatique and depression. ${ }^{17}$ Pulmonary problems did not become prominent until the beginning of 1887 , when Elias came down with a 'lung catarrh'. ${ }^{18}$

Hilda Asp was born in 1862 in the industrial town of Tampere ('the Finnish Manchester'), where her father was the master builder of a major textile factory. Hilda's education was piecemeal but exceptionally thorough for a woman of her time. After elementary school, she attended girls' schools in Tampere and Helsinki, qualified for teaching in girls' secondary schools and polished off her training with an examination in German at the University (as a private student). She taught at a girls' school in Kuopio, where she befriended the well-known realist author and social critic Minna Canth (1844-97), who encouraged her career change from teaching to acting. Elias and Hilda learned to know each other early in 1884, when she had recently moved to Helsinki to act at the Finnish Theatre, one of the hallowed cultural institutions associated with the Finnish national awakening. Hilda left her acting career in 1887,

\footnotetext{
${ }^{12}$ The three brothers were baptised Henrik, Erik and Rudolf. The Finnish forms of these names are Heikki, Eero and Ruudi or Ruuto. Rudolf adopted the first name Elias in his teens to honour Elias Lönnrot, the compiler of the national epic Kalevala. Family members called him both Elias and Ruuto, Ruudi or Ruuti. I will refer to the brothers by the names they most commonly sign their letters with: Henrik, Eero and Elias. The surname Erkko was adopted by Henrik when he studied at a teacher training institution and is derived from the name of their native farmhouse, Eerakkala. Eero Erkko's newspaper was called first Päivälehti and then Helsingin Sanomat.

${ }^{13}$ Elias Erkko, op. cit. (note 11).

${ }^{14}$ Leonore Davidoff, Thicker than Water: Siblings and their Relations, 1780-1920 (Oxford: Oxford University Press, 2012), 82.

${ }^{15} \mathrm{EE}$ to HE 2 September and 5 December 1874. The school was the first Finnish-speaking classical grammar school and, as such, an important breeding ground for the incipient Finnish-speaking educated class. It prepared boys for university, which made mere admission a sign of upward social mobility for a farmer's son. On the school, see Max Engman, 'Finns and Swedes in Finland', in Sven Tägil (ed.), Ethnicity and Nation Building in the Nordic World (London: Hurst \& Company, 1995), 189; Zetterberg, op. cit. (note 3), 82.

${ }^{16}$ EE to HE 10 September 1879, 18, 21 February, 1 March, 18 April, 9 May 1880; HE to EE 1, 5, 22 February, 19 March, 5, 23 April 1880.

${ }^{17}$ EE to HE 10 February, 14 September 1883, 30 November 1883, 24 May, 30 July 1885.

${ }^{18} \mathrm{EE}$ to HE 27 January 1888.
} 
frustrated by her moderate stage success and by what she saw as the failure of the theatre to live up to its lofty nationalist aspirations. After a while in journalism, she returned to teaching. ${ }^{19}$ Although Hilda Asp had an urban background and her father was a member of the skilled, upper layer of the working class, there were also significant similarities in her and Elias's social backgrounds. Like most of their siblings, they were committed to the Finnish nationalist cause, acquired a formal education and became part of the first generation of artists, professionals and intellectuals with roots in the common, Finnish-speaking, people.

By 1887, Elias Erkko and Hilda Asp considered themselves engaged and were starting to make preliminary marriage plans. In the summer, Elias was offered an opportunity to take a European tour as the companion of a wealthy Swedish-speaking man called Stenberg. ${ }^{20}$ Elias saw the trip as an opportunity to polish his education and gain first-hand knowledge about European culture, while Stenberg wanted to escape the harsh northern winter, which he considered harmful to his health. ${ }^{21}$ They set off in October 1887, travelling via Stockholm, Copenhagen, Hamburg, Basel, Geneva and Nice to Florence. Instead of continuing further south, as initially planned, Stenberg decided they would go to Davos, Switzerland, in the hope that the famous Davos air would cure his 'rheumatic sniffles'. ${ }^{22}$ During the preceeding decade, Davos had established itself as the foremost continental travel destination for health-seekers with respiratory problems. Apart from the salubrious air and the beautiful Alpine scenery, the village offered visitors a number of high-class hotels and a host of smaller boarding houses. ${ }^{23}$ Elias clearly did not regard himself as consumptive at this point. A doctor he saw in Davos assured him that he had no 'flaw in the lungs' (ie. consumption). ${ }^{24} \mathrm{He}$ told Hilda that he was 'eating and drinking like a bull' and taking long walks. 'Everything, then, points towards great corpulence and strong health'. ${ }^{25}$ Neither was forthcoming, however. By the end of January 1888, Elias was suffering from a catarrh and fever, which he treated with cinchona. ${ }^{26}$

The two men left Davos for Paris at the end of February. Elias was delighted to finally be in a cultural hotspot, but 2 weeks of sightseeing and late-night shows left him exhausted. In mid-March, he coughed up blood. ${ }^{27}$ Hemoptysis is a dramatic symptom closely associated with advanced pulmonary tuberculosis, and the first hemoptysis often figures as a turning point in tuberculosis-related illness narratives. ${ }^{28}$ Elias hastened to see a general practitioner, who informed him that there was no 'flaw in the lungs', prescribed arsenic and referred him to a specialist. The latter diagnosed a spot of 'ordinary consumption' in the left lung, but promised to cure it in 3 weeks with his state-of-the-art medicinal inhalations. ${ }^{29}$ Elias stayed in Paris for the treatment, while Stenberg travelled on. By the end of April, Elias's pulmonary

\footnotetext{
${ }^{19}$ Maijala, op. cit. (note 3), 161-8; Suutela, op. cit. (note 3), 124, 134, 137, 141-2, 154, 161, 181, 189-90, 194-5; Niiniluoto, op. cit. (note 3), 7-13; Liisi Huhtala, 'Asp, Hilda', Kansallisbiografia-verkkojulkaisu [Finnish national biography online] (Helsinki: Suomalaisen Kirjallisuuden Seura, 2002), at http://www.kansallisbiografia.fi/kansallisbiografia/henkilo/2811

${ }^{20} \mathrm{His}$ first name is never used in the correspondence. According to Niiniluoto, the man in question was Axel Woldemar Stenberg (1845-1931), whose family owned a mechanical factory. Niiniluoto, op. cit. (note 3), 143.

${ }^{21}$ Hanna Asp, 'Eräs nuorukaiskohtalo. 50-vuotismuisto 21.11.', Helsingin Sanomat 21 November 1938, 4, 10; EE to HE 18 April, 13 May, 25 June, 10 September 1887.

${ }^{22}$ EE to HE 29 November 1887, 5 February 1888; EE to HA 1 November 1887, 2, 4, 5, 12, 20, 23 -5 January 1888; Elias Erkko's notebook from the European tour. The quote is from EE to HE 5 February 1888. The original Finnish term is, incidentally, no less nonsensical than 'rheumatic sniffles'.

${ }^{23}$ On Davos as a retreat for the tuberculous, see Smith, op. cit. (note 8), 99.

${ }^{24}$ EE to HA 18 February 1888.

${ }^{25}$ EE to HA 14-15 January 1888.

${ }^{26}$ EE to HA 23-5, 26, 31 January.

${ }^{27}$ EE to HA 29 February, 9-11, 16-7 March 1888; EE to HE 19 March 1888; HE to EE 21 March 1888.

${ }^{28}$ This is evident for instance in the hundreds of tuberculosis-related written illness narratives collected during the 'Collection Competition for Sanatorium Tradition' [Parantolaperinteen keräyskilpailu] in 1971 by the Finnish Literature Society. The material is held by the Archive of the Finnish Literature Society in Helsinki. On hemoptysis as a turning point, see also Stacie Burke, Building Resistance: Children, Tuberculosis and the Toronto Sanatorium (Montreal \& Kingston: McGill-Queen's University Press, 2018), 227, 321.

${ }^{29}$ EE to HA 20 March 1888; EE to HE 28 March 1888.
} 
symptoms - cough, fever and pain on the right side - were accompanied by distressing abdominal symptoms: pain and severe constipation that alternated with diarrhea. He had difficulty eating and mainly subsisted on fermented milk (kefir). ${ }^{30}$

Elias left Paris on 27 May, ill and exhausted. Reluctant to return to Finland until fully recovered, he travelled to Leipzig, where Henrik was being treated by the famous hydropathic healer Louis Kuhne (1831-1901). Elias too now placed his hopes on Kuhne, who, however, refused to admit him and told him sensibly enough - to go home and let his family take care of him. When Elias was about to leave for Helsinki, he suffered another hemoptysis and decided to stay on the continent. ${ }^{31}$ During the next five and a half months, he resided in three high-altitude natural healing establishments: Reizenhain in the Saxonian mountains; an 'air cabin settlement' (Lufthüttenkolonie) in Slovenian Alps and Villa Thalysia in Meran, South Tyrol. ${ }^{32}$ In August, Hilda took a leave of absence from her teaching job and travelled to Veldes, where she found Elias miserably ill. She followed him to Meran and nursed him through the final stage of his disease. Elias Erkko died in Meran on 21 November 1888 and was buried there some days later. ${ }^{33}$

Hilda returned to Helsinki, bereft and anxious, and resumed her work as a teacher. She had been suffering from respiratory problems for some time. In March 1888, a doctor had still assured her that there was no 'flaw in the lungs', only 'ordinary catarrh'34. A year later, however, she was obviously tuberculotic. She had lost a lot of weight, coughed incessantly and suffered from throat pain. Loss of voice made teaching first difficult and then impossible. At the end of December 1890, her sister Hanna Asp (1868-1948) had her admitted to the University Hospital with advanced pulmonary and laryngeal tuberculosis. She died there on 28 February 1891 following a course of treatment with the new 'wonder drug' tuberculin. ${ }^{35}$

Henrik Erkko, too, lived much of his adult life in fear of consumption. He was often ill as a schoolboy and student and frequently on sick leave as a teacher. He identified nerves as his primary problem but often complained about chest and throat trouble, too. ${ }^{36}$ In 1887, the doctors he saw in Saint Petersburg and Helsinki could not agree whether his long-term throat ailment was tuberculotic or not. ${ }^{37}$ By March 1888, Henrik had come to believe that it was tuberculotic and embarked on a trip to Görbersdorf Sanatorium. However, on the way there he consulted a Berlin specialist who convinced him that the problem was not tuberculotic and would respond to local treatment. Henrik stayed under his treatment for a while before travelling to Kuhne in Leipzig. By this time, he had lost his faith in regular doctors and come to believe that a lasting cure could only come from natural healing. ${ }^{38}$ Henrik returned to Finland in October 1888 somewhat improved (a newspaper reported that the poet had returned, 'bringing health and auspicious vital strength with him ${ }^{39}$ ). The suspicion of tuberculosis lingered on, however, motivating several health trips abroad and a stay in Halila, the first Finnish 'air-sanatorium' for consumptives. At the beginning of 1891, Henrik was admitted to the surgical clinic of the University Hospital for treatment with tuberculin. After several weeks of medication, he was discharged without a marked change. Henrik Erkko died in November 1906 from a stroke probably caused by long-term hypertension. ${ }^{40}$

\footnotetext{
${ }^{30}$ EE to HA 21, 29 April, 1 May 1888; EE to HE 22, 23 April 1888.

${ }^{31} \mathrm{EE}$ to HA 7 June 1888 ; HE to HA 9 June 1888.

${ }^{32}$ Veldes and Meran were then both part of the Austrian Empire. The former is now known as Bled and located in Slovenia, while Meran is now in Italy.

${ }^{33}$ EE to HA 9-11, 19, 30 August 1888; EE to HE 23, 29 August, 3 September 1888; HA to EE 25 August 1888; HA to HE 10 October 1888; HA to Hanna Asp 26 September, 14, 21 October 1888; HA to Kustaa Asp 21 October, 16 November 1888; HE to EE 31 August, 3 September, 2, 11 November 1888; Kustaa Asp to HE 22 November 1888; Asp, op. cit. (note 21), 10.

${ }^{34} \mathrm{HA}$ to EE 4 March 1888.

${ }^{35} \mathrm{HA}$ to Hilda Asp 2 October 1890; HA to Gustaf Asp (father) 18 January 1889; HA to family 15 January 1891; Niiniluoto, op. cit. (note 3), 245-48; Huhtala, op. cit. (note 19).

${ }^{36}$ Jukola, op. cit. (note 3) I: 19, 156-7, 233-4, 293.

${ }^{37}$ HE to EE 21 November, 19 December 1887, 29 January, 8 April 1888; HE to Jukka Asp 18 January 1888.

${ }^{38}$ EE to HE 19 March 1888; Jukola, op.cit. (note 3) I: 293-5.

${ }^{39}$ Päivän Uutiset 17 October 1888, 2.

${ }^{40} \mathrm{HE}$ to Eero Erkko 25 July 1889; HE to P. Komonen 2 August 1890; Jukola, op. cit. (note 3) I: 301-5, II: 18, 19, 442, 449-50.
} 


\section{Looking for explanations}

In turning to the historical actors' conceptual ways of coping with tuberculosis, we are first of all struck by their pressing need to make sense of their illness - to name, explain and understand - and thereby gain some control over it, even where it might seem clear to us, with the benefit of hindsight, that the prerequisites for an adequate explanation were lacking. In doing so, they drew broadly and eclectically from shared conceptual recources and cultural scripts.

It was not easy to make sense of a disease like tuberculosis. Even naming practices were surrounded by ambiguity. Elias Erkko occasionally talked about keuhkotauti but never about tuberculosis. While keuhkotauti is the closest Finnish equivalent of consumption, the connotations of the two terms are quite different. Consumption refers to the systemic effects of the disease, to the way it consumes or eats away the body, whereas keuhkotauti literally means 'the lung disease' and is thus a squarely localist concept. In the Erkko-Asp correspondence, the most common way to refer to the dreaded disease was the non-technical, low-key expression 'flaw in the lungs' (vikaa keuhkoissa). ${ }^{41}$ This expression remained a common - probably the most common - way for lay people to refer to pulmonary tuberculosis well into the twentieth century. ${ }^{42}$ We may think of three possible reasons for people to avoid using the term 'tuberculosis': they did not know or did not accept the medical nomenclature and the thinking behind it; they did not think of themselves as suffering from the disease; or they wanted to avoid the word because of its ominous ring and social stigma.

Causation was another moot point. Elias Erkko gave it a lot of thought, struggling for years to identify and remove the causes of his ill health. A rather cerebral young man, he regarded his illness as a problem, for which he had to find the solution. Elias arrived at an understanding about the causes of his ill health as a young student. In 1883, around his twentieth birthday, he told Henrik that he had identified the twin causes of his ill health: he suffered from nervous weakness aggravated by 'genital immaturity', ie. masturbation. As he saw it, 'genital disturbances' sapped the power of his constitutionally susceptible body and pushed it over the threshold of illness. ${ }^{43}$ Despite occasional moments of doubt, Elias Erkko held on to this etiological model for the rest of his life. He regarded any form of ill health, including his increasingly debilitating respiratory and abdominal symptoms, as more or less accidental secondary manifestations of the two primary problems. There was a moment of doubt when the Parisian specialist diagnosed consumption and Elias admitted to Henrik that there really was 'a regular consumption at an early stage in my left lung' ${ }^{44}$. However, Elias soon reverted back to his etiological model, aided by Henrik, who was reluctant to believe that his beloved little brother really had 'a flaw in the lungs' ${ }^{45}$.

Elias was far from alone in believing in the pathological power of masturbation or weak nerves. His disease conception does not seem to have been contested by Dr Holmberg, the Helsinki physician he saw on Henrik's recommendation in 1883, and he also found support for it in popular medical literature. ${ }^{46}$ Henrik, his primary sounding board, readily agreed with him. ${ }^{47}$ Indeed, Henrik had probably been

\footnotetext{
${ }^{41}$ The Finnish word vika could be rendered not only as 'flaw' or 'fault' but also as 'damage' or 'malfunction'. English names used for pulmonary tuberculosis in the nineteenth century included eg. consumption, phthisis, decline, wasting disease, delicacy of the lungs and lung weakness. Smith, op. cit. (note 8), 2.

${ }^{42}$ In Parantolaperinteen keräyskilpailu (note 28), whose contributions were mainly written in 1970-71 and tackled events that took place between the early 1920s and 1970, 'flaw in the lungs' is still a common way to refer to pulmonary tuberculosis. Finnish folklore scholar Katja Hyry, in her study on her great grandmother, who died from tuberculosis in the 1930s, also observes that her relatives never used the word tuberculosis, not even when they were treated in a tuberculosis sanatorium. Katja Hyry, Iida. Löytöretki isoäitini äidin elämään (Helsinki: Katja Hyry, 2018), 167.

${ }^{43} \mathrm{EE}$ to HE 21, 28 April 1883.

${ }^{44} \mathrm{EE}$ to HE 28 March 1888.

${ }^{45}$ EE to HE 5 April 1888.

${ }^{46} \mathrm{EE}$ to HE 30 November 1883, 30 July 1885. One popular health manual that Elias Erkko mentions by name is $\mathrm{Om}$ ungdomens sedliga uppfostran, written by 'an English physician'. The book is likely to be the Swedish translation of Elizabeth Blackwell's Counsel to Parents on the Moral Education of Their Children (New York: Brentano's Literary Emporium, 1880). Blackwell warns against masturbation, which she regards as loss of self-control and a vice that easily leads to other vices. She also asserts that it is fully possible for men, too, to abstain from premarital sex.

${ }^{47} \mathrm{HE}$ to EE 24 April 1883.
} 
instrumental in acquainting Elias with the nerve lore, for his own letters are littered with references to the havoc that weak nerves were causing in his life. ${ }^{48}$ Henrik also told Elias that he and Eero had had their share of nervous trouble and 'genital immaturity' and that it was common for artists and intellectuals to suffer from weak, irritable nerves. ${ }^{49}$ Henrik and Elias believed that their nervous weakness had a hereditary component. Having heard Elias's confession about the causes of his ill health, Henrik commented: 'I am appalled to see that our home, which has blessed us with natural talents, has also marked us with a curse ${ }^{50}$. This notion was not in disagreement with the prevailing medical view of tuberculosis, which still ascribed a major role to heredity. What was inherited was not so much an elevated risk of a specific disease but rather a pathological disposition or, as Michael Worboys puts it, a set of 'constitutional proclivities' ${ }^{51}$. The same faulty disposition that had manifested itself as alcoholism in the father could thus manifest itself as consumption in the sons.

Educated Europeans had been fascinated by the nerves since the eighteenth century, when it had become fashionable to explain not only disease(s), but also many individual, social and national differences with reference to the nervous system and nervous power. Scientific support for the nervecentred view of the human being could be found, for instance, in the works of Albrecht von Haller (170877), who regarded sensibility, the ability to react to external stimuli, as the universal property of the nerves, and William Cullen (1710-90), who explained constitutional differences with reference to the sensibility and irritability of the nerves, and asserted that all diseases had a nervous component. Scottish physician John Brown (1735-88) went a step further and drafted a theory according to which all pathological states ultimately derived either from sthenia (excessive excitability) or from asthenia (insufficient excitability). Brunonism gained wide currency in both lay and medical circles in the late eighteenth and early nineteenth centuries. It was a key element in the speculative medicine of German Romanticism, which in turn provided the philosophical underpinnings of the natural healing movement that the Erkko brothers found so appealing. ${ }^{52}$ At a time when the humoural theory already had lost much of its scientific authority and the workings of the immune system were not yet known, 'nervous power' provided a much-needed holistic and individualising way to explain why some people succumbed to disease and others did not.

The link established between consumption and depleted nervous power opened a way for the romantisation and aesthetisation of the disease in nineteenth-century culture, as explored by Susan Sontag and others. Carolyn Day has discussed the changes undergone by the rhetoric and imagery of consumption in the course of the century. During the first part of the century, the (young, middle-class) consumptive was presented as a sensitive, morally refined, inwardly and outwardly beautiful, perhaps precociously talented individual. During the latter part of the century, the disease continued to be heavily loaded with cultural connotations but was morely likely to be associated with negative things such as excess and lack of control, effeminacy, sensuality and moral depravity. ${ }^{53}$ The former way of representing consumption - I will call it the romantic-sentimentalist script - never gained a strong foothold in

\footnotetext{
${ }^{48}$ For example, HE to EE 18 September 1878, 1 February, 29 March, 2 December 1880, 16 September 1882, 8 August 1886, 25 April, 21 March 1888.

${ }^{49} \mathrm{HE}$ to EE 21 March, 8 April 1888.

${ }^{50} \mathrm{HE}$ to EE 24 April 1883.

${ }^{51}$ Worboys, 'From Heredity' op. cit. (note 8), 81.

${ }^{52}$ José M. López Piñero, Historical Origins of the Concept of Neurosis, translated by D. Berrios (Cambridge: Cambridge University Press, 1983), 12, 18-9; Fay Bound Alberti, 'Emotions in the early modern medical tradition', in Fay Bound Alberti (ed.), Medicine, Emotion and Disease, 1700-1950 (Houndmills, Basingstoke: Palgrave Macmillan, 2006), 12-6; Lars-Christer Hydén, 'Body and soul: Soma and psyche as cultural and narrative resources', in Jonas Frykman, Nadia Seremetakis and Susanne Ewert (eds.), Identities in Pain (Lund: Nordic Academic Press, 1998, 29-49), 49-50; Day, op. cit. (note 10), $34-5$. Research on the nervous system and sensibility in the eighteenth century is plentiful, especially as concerns England. Examples include Anne Jessie van Sant, Eighteenth-Century Sensibility and the Novel: The Senses in Social Context (Cambridge: Cambridge University Press, 2004); George Rousseau, Essays on Literature, Culture and Sensibility (Palgrave Macmillan, 2004); Paul Goring, The Rhetoric of Sensibility in Eighteenth-Century Culture (Cambridge: Cambridge University Press, 2005).

${ }^{53}$ Day, op. cit. (note 10) 55, 129-32.
} 
Finland. The social substratum that primarily fostered the script in Britain - the affluent urban middle class with clearly separate spheres of action assigned for men and women - was very thin in Finland at the time. Moreover, Finnish language did not yet exist as a literary language during the heyday of the Romantic movement. One is hard pressed to find romantic-sentimentalist representations of consumption in Finnish literature or art. ${ }^{54}$

Henrik Erkko, however, drew from the romantic-sentimentalist script in at least one juncture, in the texts (a biographical essay and several poems) that he wrote about his dead brother between 1888 and 1901. In the spirit of romanticism, these texts evoke a young man who was lovable and pure, full of talent and potential, idealism and integrity, but whose 'slight powers', 'tender character' and 'delicate mind' made him incapable of withstanding the pressures and stressors of contemporary life. ${ }^{55}$ Elias Erkko himself seldom spoke about his disease in metaphorical or emotional terms, but when he did, he associated it with weakness, shame and even depravity rather than sprituality and refinement. His fear for being pitied as an invalid was the main reason he did not want to return home until completely cured. He felt that being ill detracted from his masculinity and tainted his life and even his looks. When Hilda commented that he looked beautiful in a photograph, Elias countered that there was 'something morbid' around his mouth. ${ }^{56}$ Elias Erkko thus drew from the realist-naturalist rather than romanticsentimentalist script in discussing his illness. Befittingly, weak nerves, hereditary taint and the notion of degeneration were central themes in naturalistic literature, the genre that Erkko championed. ${ }^{57}$

The pathological potential of masturbation had been a medical and popular commonplace since the latter half of the eighteenth century. ${ }^{58}$ Medical and educational texts carried long lists of pathological conditions that could be caused or aggravated by masturbation. Consumption figured on those lists, and many of the outward signs and symptoms of consumption were also associated with habitual masturbation: pallor, 'sunken' outlook, listlessness, sleep disturbances, weight loss, even bloody expectorations or vomit. ${ }^{59}$ Historian Thomas Laquer notes that there was 'a century-long tradition that believed that the masturbator was an easily recognizable type ${ }^{360}$. Elias ascribed to this notion. Walking the streets of Helsinki, he believed he could see how widespread the solitary vice was. ${ }^{61}$ And it also worked the other way around: During a confidential late-night conversation, a male acquaintance told Elias that he could be recognised as a masturbator 'by the hue, by the face'. ${ }^{62}$ The fact that the first signs of pulmonary tuberculosis typically manifested themselves in puberty supported the assumption that there was a causal link between tuberculosis and masturbation.

\footnotetext{
${ }^{54}$ The art historian Tutta Palin has sought descriptions of illness, particularly tuberculosis, in Finnish fine art, and come up with very little. She asserts that when illness was depicted it was likely to be depicted in the realist or naturalist rather than romantic or decadent idiom. Tutta Palin, 'Sairauden moderni ikonografia', in Jutta Ahlbeck et al. (eds.), Kipupisteissä. Sairaus, kulttuuri ja modernisoituva Suomi (Turku: UTUkirjat, 2015, 33-74), 35, 64, 65.

${ }^{55}$ The poems are called 'The Autumn Song', 'Elias Erkko' (dated in 15 December 1888), 'The Veldes Valley', also known as 'The Third One', 'The Dark One and the Fair One', 'The Spring Song of Sorrow' and 'The Fallen Young Man', later published under the title 'Why?' Most of them have been reprinted in J.H. Erkko, Kootut teokset 2: Runoelmia 1886-1906, released by Project Gutenberg on 2 May 2006 (http://www.gutenberg.org/ebooks/18301). After Elias's death, Henrik started to prepare the publication of a volume containing the manuscript of Elias's play and some of his poems. He edited the volume and wrote a biographical introduction for it, and Eero Erkko covered the cost of the publication. Elias Erkko, op. cit. (note 11).

${ }^{56} \mathrm{EE}$ to HA 20 March, 2, 11-12, 14 April 1888; EE to HE 5 April 1888. The quote is from EE to HA 27 January 1887.

${ }^{57}$ Disease, weak nerves and degeneration were central themes in Minna Canth's work. Maijala, op. cit. (note 3) $222,230$. Canth was a leading naturalist author and Elias Erkko's friend and mentor. The theory of degeneration was based on the pessimistic assumption that the sum total of hereditary problems incerased from one generation to the next.

${ }^{58}$ On the history of masturbation, see Thomas Laquer, Solitary Sex: A Cultural History of Masturbation (New York: Zone Books, 2003); Jean Stengers \& Anne van Neck, Histoire d'une grande peur. La masturbation (Bruxelles: Institut Synthélabo, 1998); H. Tristam Engelhardt, 'The Disease of Masturbation: Values and the Concept of Disease', Bulletin of the History of Medicine 48 (1974), 234-48.

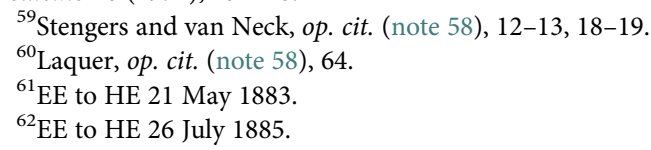


Elias, Henrik and Hilda also referred to a host of secondary exciting factors in their letters and writings. Bad air, physical inactivity, mental excertion and emotional strain loom large in their etiological speculations. As much as the two Erkko brothers valued education, they also regarded school work, which involved both mental strain and long hours of sitting and reading in poorly ventilated and heated rooms, as a major health risk. ${ }^{63}$ The texts that Henrik wrote after Elias's death anxiously quizzed how a person who had been leading such a 'decent, irreproachable' life could have succumbed to tuberculosis. Henrik's list of proposed causal factors is a mixed bag, ranging from 'the sins of the previous generations' and 'the collective illness of society' to cold and draft, from disappointments and strong emotions to wrong sort of reading material. Even Elias's love for Hilda now emerged as a pathogenic influence: 'These two burning souls, almost bodiless, consumed each other too soon' ${ }^{64}$

Elias Erkko's explanatory model remained distinctly pre-Kochian. He never referred to bacterial causation, asked where or how he might have been infected, or worried about infecting others. He did not regard his lung, stomach and kidney problems as so many forms of tuberculosis, but as distinct diseases due, in the last instance, to his constitutionally weak nerves. After Elias's death, Hilda and Henrik adopted the bacterial conception of tuberculosis, without necessarily renouncing other explanations. In a newspaper article that Henrik wrote on his treatment with tuberculin in 1891, he acknowledged the bacterial causation as a fact and anthropomorphised his new-found enemies. ${ }^{65} \mathrm{He}$ hated the members of that 'mean' and 'enduring breed' but also envied them, because, unlike him, they could 'rejoice in their wild pleasure', without being rejected by their peers. ${ }^{66}$ Together with bacterial causation, social stigma and fear of contagion had also entered the picture.

\section{Looking for cure}

The conception of disease that people hold influences what sort of treatment they seek, how much they are willing to invest in and the extent to which they commit to different forms of treatment and the way they interpret the treatment results. Naturally, people's treatment choices also depend on the availability and accessibility of treatment and thereby on their financial and social resources.

The first thing to note is that Hilda Asp and the Erkko brothers really fought for their health. As the historian Antti Harmainen has pointed out, '[Elias] Erkko and those close to him did not just wait for the end but sought effective treatment from various fields of international research-based knowledge until the very end ${ }^{\prime 67}$. Given that fatalism was a trait associated with the peasentry, a proactive attitude and an emphasis on self-discipline and self-control was also a way for middle-class people to distinguish themselves from the peasantry, from which many of them had only recently emerged. Of course, economic, social and cultural resources also mattered. Although anything but rich, Hilda, Henrik and Elias nevertheless belonged to the small educated section of the population and thus to the privileged few. They spoke and read several languages and their extensive social networks included well-read, welltravelled and also some wealthy individuals. When ill and in dire straits, they could turn to the latter for help. For instance, when the penniless Elias wanted to stay in Paris for the inhalation treatment, Hilda and Eero used their social networks to procure him a series of small loans.

The therapeutic practices that the three resorted to ranged from archaic and partly obsolete to novel and experimental. The Erkko brothers alleviated their symptoms with folk remedies they knew from their childhood home, and the daily regimen they prescribed themselves closely coincided with the 'the

\footnotetext{
${ }^{63} \mathrm{HE}$ to EE 1, 5 February, 19, 23 March 1880, 9 June 1885; EE to HE 23 June 1880, 25 April 1885. On study and intellectual work as risk factors of consumption, see also Rothman, op. cit. (note 10), 28, 31, 45.

${ }^{64}$ Erkko, op. cit. (note 11), Erkko, op. cit. (note 55); Hanna Asp to HE 14 April 1901.

${ }^{65}$ The article ('Lymfattu') was published anonymously, but it is obviously written by Henrik Erkko. It was published in Eero Erkko's newspaper Päivälehti, and an almost verbatim draft can be found in Henrik Erkko's notebooks at the Päivälehti Archives. 'Lymfattu', Päivälehti 4 March 1891, 3; 26 March 1891, 3.

${ }^{66}$ 'Lymfattu', op. cit. (note 65), 4 March 1891, 3.

${ }^{67}$ Harmainen, op. cit. (note 3), 381.
} 
six non-naturals' of Galenic medicine. Supervised by Henrik, Elias paid close attention to his diet, sleep and exercise as a schoolboy and student. He did not smoke or drink alcohol (at least not excessively), tried to maintain a balanced diet, limited his working hours and counterbalanced scholarly work by walking in fresh air and exercising regularly at the University's Gymnastic Institute, where he also worked as a parttime assistant. Attention to 'expulsion and retention' was there, too, in the form of concern for bowel movements and involuntary ejaculations, and the role of emotional factors in disease causation was also recognised by the Erkko brothers. ${ }^{68}$

Remedies were sought both home and abroad. Travelling for health was a well-established practice among upper- and middle-class Europeans, especially those with pulmonary problems. It was facilitated by the expanding rail services and the permeable national borders characteristic of pre-WWI Europe. Elias Erkko did not initially embark upon his European tour for health reasons, but he and Hilda clearly entertained the hope that travelling might do him good. Stenberg travelled for health, as did Henrik Erkko. Despite the physical excertion and discomfort involved, travelling as such was not considered risky for a consumptive (as it would be in the twentieth century). The expenses were accepted as a sensible or even necessary investment in health. The justification for health travel was twofold. First, it allowed Finns to see leading specialists in European medical centres and visit famous alternative healers in their headquarters. The second justification was the age-old belief that consumption was susceptible to environmental influences and that certain places excerted a healing influence on people suffering from it.

In this pursuit for healthy environments, air was the central consideration. The quality of air was a theoretically overdetermined factor, being a key element in several medical scipts. Air was one of 'the six non-naturals' and the core component of the miasma theory. It was the main curative element in most schools of natural healing, at least in the case of pulmonary diaseases. Both traditional phthisiology and the climatic theories underpinning the incipient sanatorium medicine highlighted the importance of air quality. Wherever Elias stopped during his European tour, he made a note about the air quality and pondered upon its influence on his condition. Stenberg had high hopes for the reputedly salubrious Davos air. The Erkko brothers' travel recommendations to each other often revolved around air quality. Choosing the right destination was no simple matter, for the quality of air in a given location might change from one season to another, and air that was good for one ailment might not work on another. ${ }^{69}$ The assurance of a Parisian doctor that Paris summer air would benefit his lungs was one of the things that made Elias stay there. Hilda found the doctor's claim ludicrous, given that 'There is no forest air, which is necessary for chest patients, within miles'70.

Except for the very last phase of his illness, Elias Erkko did not reject the services of regular medical practitioners either. The latter provided both symptomatic remedies and constitutional prescriptions. Doctors prescribed Elias, Henrik and Hilda iron, arsenic and cocawine for general weakness and listlessness, frangula for constipation, cinchona for fever, opium for cough. Porter, beer and brandy were consumed for medicinal purposes. ${ }^{71}$ A Parisian general practitioner treated Elias's pulmonary problems with an irritating poultice that caused a painful blister on his side. ${ }^{72}$ Poultices had been part of physicians' toolbox for hundreds of years, and doctors still occasionally applied them, although irritating poultices had lost their theoretical grounding in the humoural theory and were fast becoming obsolete. Blood-letting, another mainstay of humoural medicine, was already passé in the treatment of tubercu$\operatorname{losis}^{73}$, and there are indeed no references to blood-letting in the Erkko-Asp correspondence.

\footnotetext{
${ }^{68}$ EE to HE 9 September 1882, 10 February 1883; HE to EE 1, 5, 22 February, 19, 29 March 1880, 5, 23 April, 4 May 1880, 15 February 1883.

${ }^{69}$ EE to HA 4, 11, 16 February 1888; EE to HE 29 November 1887, 5, 9 February 1888; HE to EE 8 month unclear 1888; HE to EE \& HA 2 November 1888.

${ }^{70} \mathrm{HA}$ to EE 28 May 1888.

${ }^{71}$ EE to HE 10 October 1880; EE to HA 16 February, 11-12, 14 April 1888; HE to EE 5 April 1880, 16 November 1880; HA to HE 13 March, 25 May 1888.

${ }^{72}$ EE to HE 24 May 1888; EE to HA 11-12, 14 April, 20-21 May 1888.

${ }^{73}$ Smith, op. cit. (note 8), 9.
} 
Some doctors' prescriptions were designed to strengthen the constitution rather than just alleviate symptoms. The Helsinki practitioner that Elias saw in 1883 told him not to stay in bed for more than 8 hours at a time; to rub his body with a cold wet towel and take a short walk each morning; to bathe frequently in the winter and swim regularly in the summer and to continue with gymnastics and to take iron preparations in autumn and spring. ${ }^{74}$ The regimen, whose purpose was clearly to strengthen the body and to curb sexual desire, reflected prevailing views about the male body and its vulnerabilities. Gymnastics, swimming and bathing were considered effective ways of enhancing masculinity and discouraging masturbation. ${ }^{75}$

In Paris, Elias fell into the hands of a ruthless medical entrepreneur, the likes of which could be found in any medical metropolis. The specialist diagnosed a small flaw in one lung and promised to cure it within 3 weeks with his innovative medicinal inhalations. Elias was sceptical about the specialist's bloated claims but did not dare to leave the treatment untried. For the next two and a half months, he went to the specialists' office almost daily, except when bedridden, to inhale a gas that probably did him more harm than good. ${ }^{76} \mathrm{He}$ described the procedure to Hilda in some detail:

Every day from two to three [o'clock] I inhale in my doctor's office. They put me in a little booth that is furnished with nothing but a comfortable armchair. There I sit and make myself comfortable and inhale all I can for an hour. Meanwhile, 'the curative vapour' flows in through a pipe. Its name in that Greek-Latin they use in French medicine is 'inhalation d'acide fluorhydrique'. My doctor has almost twenty booths like that. It is a new, 'most excellent' treatment, has 'produced amazing results', is one of the flowers of French medical art etc. etc. Which, by the way, also shows in the price. ${ }^{77}$

Doctors had been treating consumptives with inhalations for some time. ${ }^{78}$ However, the specialist assured Elias that the treatment was available only in Paris, and Elias's own inquiries seemed to confirm that the procedure was indeed not known in Finland. This made him prolong his stay in Paris and to use a lion's share of his borrowed money on an expensive inhalation booth to take home with him. ${ }^{79}$

The struggle against 'the solitary vice' was another profitable niche of the medical market. The masturbator was offered instructive printed material, potions, pills, mechanical devices and surgical procedures. ${ }^{80}$ In Paris, Elias reasoned that since his lung problems were secondary and accidental and nervous and genital problems primary and fundamental, he should 'go to a doctor who specialises in the genital organs' rather than a lung specialist. He did see a urologist but was unable to afford his services at the time. ${ }^{81}$ A Parisian urologist would have seen great many anxious young masturbators and no doubt have sold Elias advice, medication or other means of combating the habit.

The correspondence between Elias and Henrik contains several references to sexual intercourse as a remedy for masturbation. In 1885, the acquaintance who purported to have recognised Elias as a habitual masturbator told him that 'you will soon die if you do not quickly go see women', 82 ie. engage the services of a prostitute. Elias wrote Henrik that he was not prepared to follow the man's advice, for it was not 'the same for me as it is for him. If I did that, I would be cut loose - I would cut myself loose - from my whole past and would have to build on a new ground, without any tradition and outward support'. ${ }^{83}$ In other

\footnotetext{
${ }^{74}$ EE to HE 28 April 1883; HE to EE 24 April 1883.

${ }^{75}$ Stengers and van Neck, op. cit. (note 58), 19; Jonas Frykman, 'On the hardening of men', in Jonas Frykman, Nadia Seremetakis and Susanne Ewert (eds.), Identities in Pain (Lund: Nordic Academic Press, 1998), 128-9.

${ }^{76}$ EE to HE 19, 28 March 1888; EE to HA 16-17, 20 March 1888.

${ }^{77} \mathrm{EE}$ to HA 20 March 1888. It would seem that he was inhaling was hydrogen fluoride gas, an irritating and potentially lethal substance.

${ }^{78}$ Day, op. cit. (note 10), 27-8; Smith, op. cit. (note 8), 45-6, 64, 66.

${ }^{79} \mathrm{EE}$ to HA 26 May, 4 June 1888.

${ }^{80}$ Laquer, op. cit. (note 58), 16-17, 20, 38, 40-4; Stengers and van Neck, op. cit. (note 58), 13-4, 23-5, 16, 18-19, 122-7.

${ }^{81} \mathrm{EE}$ to HE 13 April 1888.

${ }^{82} \mathrm{EE}$ to HE 26 July 1885.

${ }^{83}$ EE to HE 26 July 1885.
} 
words, Elias did not question the idea that sexual intercourse might free him of masturbation and thereby restore his health, but he felt that buying sex would force him to radically rethink his values, even reconstitute his identity. It was a price he was not willing to pay, at least not at this point.

As far as prostitution was concerned, personal was also political. Elias's personal dilemma was closely related to one of the most heated social controversies in Finland in the 1880s, namely the so-called sexual morality issue (siveellisyyskysymys). In Finnish historical scholarship, the controversy is usually described as the clash between 'relative' and 'absolute' morality, ${ }^{84}$ but it would be more befitting to call it the clash between single and double standards. One party claimed that both men and women could and should abstain from pre- and extramarital sex, while the other insisted that there was no realistic alternative to the prevailing double standard. The latter camp, which included the vast majority of the medical profession, argued that it was futile and downright dangerous for men to abstain from premarital (and extramarital) sex and that (regulated) prostitution was therefore a necessity. The profession thus seemed to regard the risk of venereal disease involved in prostitution (also in regulated prostitution) as a lesser evil than the risks related to masturbation and abstinence. Hilda and Elias were highly aware of the twists and turns of the debate and had a personal intellectual, moral and emotional stake in it. ${ }^{85}$

Elias's last resort was natural healing. He arrived to Leipzig bitterly disappointed with regular physicians, who had taken his money and done nothing to improve his health. Henrik, who was by now an enthusiastic champion of natural healing in general and Kuhne in particular, fanned Elias's mistrust in regular medicine. As they now saw it, school medicine stood for tradition, elitism and authoritarianism, while natural healing was the medicine of the future. While 'old' medicine treated symptoms only, natural healing targeted the heart of illness, the constitutional weakness. A lasting cure required the whole organism to be 'regrounded'. Another key term in this script was 'crisis', ie. the culmination of the battle between the pathological process and the innate healing powers of the body. ${ }^{86}$ Hilda, who was decidedly less enthusiastic about natural healing than Henrik and Elias, remarked wryly: "Well they [natural healers] do have the handy fallback measure that there can be many more "crises" and it depends on the vital force whether one survives them or not. Very convenient'. ${ }^{87}$

Natural healers swore by the remedial qualities of water, air, sun and vegetarian food. Different healers prioritised different elements and administered them by somewhat different means. Kuhne's well-known method consisted of a complex system of baths, showers and poultices. The therapeutic regimen of Reizenhain Kurhaus, where Elias transferred from Leipzig, rested on mountain air and vegetarian diet. After 3 months there, Elias had lost faith in 'Rhain' and its director Carl Griebel, but not in natural healing. He convinced himself that Arnold Rikli (1823-1906), a famous naturopath based in Veldes (in the Slovenian part of what was then the Austrian empire) could save his life. Elias's first letters from Veldes describe Rikli's 'Air Cabin Colony' (Lufthüttenkolonie) in enthusiastic detail. The settlement was located in a beautiful Alpine valley, where patients occupied little cabins overlooking a clear lake. Air circulated unhindered in the cabin, as one side was completely open and the three walls had openings.

\footnotetext{
${ }^{84}$ The controversy has been discussed in eg. Arja-Liisa Räisänen, Onnellisen avioliiton ehdot. Sukupuolijärjestelmän muodostumisprosessi suomalaisissa avioliitto- ja seksuaalivalistusoppaissa 1865-1920 (Helsinki: Suomen Historiallinen Seura, 1995), 48-9; Pirjo Markkola, Synti ja siveys. Naiset, uskonto ja sosiaalinen työ Suomessa 1860-1920 (Helsinki: SKS, 2002), 165-6; Minna Uimonen, 'Lihan viekkaus, tavan mahti ja harkinnan vapaus. Hanna Ogelin ja siveellisyyden kontekstit 1800-luvun lopun suomalaiskeskustelussa', in Tuija Pulkkinen and Antu Sorainen (eds.), Siveellisyydestä seksuaalisuuteen. Poliittisen käsitteen historia (Helsinki: SKS, 2011), 108.

${ }^{85}$ They discussed the debate in their letters and touched upon it in their publications. Minna Canth was also deeply involved in the debate. For example, Minna Canth, 'Siveellisyys-asia', Valvoja 7 (1887), 156-9; Hilda Asp's diary 9 October 1889, cited in Niiniluoto, op. cit. (note 3) 237; Es.Eo. [Elias Erkko], 'Kirje Helsingistä (Gustaf af Geijerstam)', Keski-Suomi, 19 March 1887, 12; H.A. [Hilda Asp], 'Siveellisyysoloista maaseudulla', Excelsior. Kalenteri vuonna 1888 (Helsinki: Suomen Nais-Yhdistys, 1887), 49-60. Elias Erkko's play Elinan surma revolves around the issue of sexual morality, transplanted in medieval Finland.

${ }^{86}$ EE to HA 26 June 1888; EE to HE 5 February 1888; EE to Axel Gallén 16 September 1888; EE \& HE to HA 7 June 1888 ; HA to EE 2 January, 29 April, 31 August, 11 September 1888; HA to Hanna Asp 26 September 1888; HE to EE 11 September 1888.

${ }^{87}$ HA to Hanna Asp 2 October 1888.
} 
Patients bathed in the lake and took walks on the grounds. They wore cotton string vests and rolled-up pants to draw maximum benefit from air and sun. Stronger patients would climb to the top of the nearby hill each morning, take off their clothes and spent the day there, exposed to the elements. ${ }^{88}$ 'In Rhain they always talked about the air, here they use it', Elias remarked approvingly. ${ }^{89}$

It is not difficult to see why natural healing appealed to the Erkko brothers. The remedies offered by regular medicine were almost exclusively symptomatic. Prescriptions were often contradictory, treatments expensive and/or painful. More often than not, they were also ineffective. The mechanism by which they were supposed to work was usually not known, and therefore they seemed to be based on nothing but obscure medical authority. In comparison, the principles of natural healing seemed transparent and clear, and the active ingredients (air, water and sunlight) were readily available and harmless. Their application was usually painless. Natural healing was also more democratic than regular medicine, as it required no formal education. Rikli had been a tanner, Griebel an opera singer. In July 1888 , Elias contemplated on becoming 'so adept at the natural method of healing that I will not need any other doctors even back in Finland'. ${ }^{90}$ In the eyes of cultural nationalists like the Erkko brothers, the Völkisch aspect of natural healing was another factor speaking in its favour. ${ }^{91}$

Hilda Asp did not share the Erkko brothers' enthusiasm for natural healing. She was more favourably disposed towards licenced practitioners than they were, perhaps because of her urban background. She defended regular medicine against Elias's mounting criticism, insisting that Finnish doctors can be trusted even if foreigners cannot. She suspected that vegetarian diet did not suit Elias, an issue on which the practically minded Eero Erkko seconded her. Rikli's air cabins failed to impress her. ${ }^{92}$ Her attitude towards natural healing changed somewhat in Meran, largely out of necessity. The owner of Villa Thalysia prescribed a strict vegetarian diet and rejected all active forms of treatment. Much of the daily nursing was left to Hilda, who learned to cook vegetarian food and composed a treatment regimen from different hydropathic elements. ${ }^{93}$ When Elias seemed to be doing better, Hilda dreamt of becoming a natural healer and curing her epileptic sister. ${ }^{94}$ When he was worse, she was painfully uncertain about the way to proceed. She wrote to her brother Kustaa, who was residing in Berlin at the time, that 'occasionally I am visited by the horrible thought that perhaps old [ie. regular] physicians and strong food would cure him after all. And here I am, watering him to death!' ${ }^{95}$ She continued to be tormented by such doubts after Elias's death, to the extent that she decided, on Henrik's advice, to consult a Berlin psychic, who was instructed to ask Elias who was responsible for his death. ${ }^{96}$ Disappointed with the result, Hilda summed up the experience: 'Like everything else, it [spiritualism] is of course faith-dependent humbug from beginning to end'. ${ }^{7}$

The one thing that Elias Erkko did not try was sanatorium treatment. This was not out of ignorance. Elias, Henrik and Hilda were well familiar with the reputation of Görbersdorf and knew people who had been treated there. In February 1888, when Henrik was trying to decide where to seek help for his throat ailment, Elias told him that Görbersdorf had 'a very energetic physician, who keeps his patients in strict discipline and thereby accomplishes a lot, but the place is rather bleak - hospital as it is - and quite

\footnotetext{
${ }^{88}$ HE to HA 9 June 1888; EE to Axel Gallén 12 June 188; EE to HA 19 August 1888; HA to EE 25 August 1888; HE to EE 31 August 1888.

${ }^{89}$ EE to HE 29 August 1888.

${ }^{90} \mathrm{EE}$ to HA 30 July 1888.

${ }^{91}$ J.H.E. [Erkko, J.H.], 'Eräästä luontoparantolasta Itävallassa', Uusi Suometar 14 October 1888, 2.

${ }^{92}$ EE to HA 4 June 1888; HA to EE 30 May, 2 July, 25 August 1888; HA to HE 2 September 1888; HA to Hanna Asp 26 September 1888; Eero Erkko to EE 4 November 1888; HE to EE 6 November 1888.

${ }^{93} \mathrm{HE}$ to EE \& HA 2, 11 November 1888; HA to HE 10, 21 October, 4 November 1888; HA to Hanna Asp 14 October, 10 November 1888; HA to Gustaf Asp (father) s.d. [October-November 1888]; HA to Kustaa Asp 6, 16 November 1888; Asp, op. cit. (note 21), 10.

${ }^{94}$ HA to Kustaa Asp 9 November 1888; HA to HE 15 December 1888.

${ }^{95} \mathrm{HA}$ to Kustaa Asp 6 November 1888.

${ }^{96}$ HA to HE 15 December 1888; HA to Kustaa Asp 17 December 1888.

${ }^{97} \mathrm{HA}$ to HE 6 January 1889. See also HA to HE 25 January 1889.
} 
confining. ${ }^{98}$ Hilda Asp and Erkko Eero would have rather seen Elias in Görbersdorf than in a natural healing establishment, ${ }^{99}$ but Elias was adamant that he was familiar with all treatment options, including Görbersdorf, 'almost as well as I had been there myself, and convinced that it was not the place for him. ${ }^{100}$ The conviction probably sprang both from his dislike for medical authorities and from his belief that his problems were not rooted in the lungs.

In early 1891, Henrik and Hilda were amongst the first patients treated with the novel 'wonder drug' tuberculin in Finland. Their 'lymph treatment' coincided with the short heyday of tuberculin. Koch's announcement of a new anti-tuberculotic drug in August 1890 had been met with massive media attention, and sufferers from all over the world had flooded to Berlin. ${ }^{101}$ Hilda's doctor, too, had suggested a trip to the German capital, but she had decided to wait until the drug became available in Finland and predicted that 'many will call Koch a charlatan before the end of the year'. ${ }^{102}$ Richard Sievers (1852-1931), Finland's leading tuberculosis expert, brought the first two bottles of tuberculin from Berlin to Helsinki on 29 December 1890 - a feat reported in all major newspapers. One bottle went to the New Clinic (an internal clinic) and the other to the Surgical Clinic, where the first injections were given already the next day. ${ }^{103}$ Hilda was admitted to the former, Henrik to the latter clinic.

On entering the New Clinic at the beginning of January, Hilda jotted down some private notes. She was greeted with 'the smell of carbolic acid' and observed that the interior surfaces were smooth and clean, the corners caved and the ceiling high - features that she took as a sign that 'bacilli have no place here, and there seems to be enough air'. ${ }^{104}$ Her short note thus emcompasses the guiding principle of nineteenth century pavilion hospital design - the free circulation of air, - the more recent antiseptic principle, and the novel bacteriological thinking. Hilda Asp's treatment with tuberculin started with 0.5 $\mathrm{mg}$ injections that caused a strong general reaction (as tuberculin usually did). She suffered from palpitations, temperature rise, lassitude and sleeplessness. ${ }^{105}$ Her condition continued to deteriorate, and she died at the hospital on 28 February. ${ }^{106}$

Henrik wrote a long newspaper piece on his experiences at the Surgical Clinic. He recounted how he entered the 'palatial' Surgical Hospital on 2 January with his 'mind full of hope', his trust in tuberculin matching his former enthusiasm for Naturheilkunde. ${ }^{107}$ He was taken to the operating theatre, where doctors in their white coats surrounded him like a flock of seagulls. They auscultated, palpitated, exchanged learned words and eventually injected a few drops of glittering brownish liquid under the skin in his back. To the surprise of both the patient and his doctors, there was no reaction at all, not even after a prolonged course of treatment that included several record-high doses. Finally, Henrik was told by the director of the clinic that 'Koch cannot make me any better. All lymph that can be given has been given'. His sputum was bacteriumfree, and he did not look or feel sick. But he found it very hard to console himself with the thought that he did not suffer from tuberculosis and was already planning where to turn next: 'I have read in newspapers that they are planning to start using Professor Leibreich's Kantharin here, too. Maybe it would bring me final help. And if not it, then a Mr Ewald is also said to have accomplished something. Then there is goat's blood, that the French say is good, and goat's milk has also been tried with success in Finland. Aided by nature, some of them will help'. ${ }^{108}$ There was no shortage of treatment options, nor of desperate people willing to try them.

\footnotetext{
${ }^{98}$ EE to HE 5 February 1888.

${ }^{99}$ EE to HA 19 August 1888; HE to EE 31 August 1880; HA to EE 25 August 1888.

${ }^{100}$ EE to HA 8 September 1888 .

${ }^{101}$ The drug became commercially available in Germany on 13 November 1890. Gradmann, op.cit. (note 7), 95, 102-3.

${ }^{102}$ HA to Hanna Asp 24 November 1890. According to Christopher Gradmann, 'the euphoria about the medication died down by the end of the year', op. cit. (note 7), 103.

${ }^{103}$ 'Helsingissä', Suomalainen Wirallinen Lehti, 31 December 1890, 1; 'Kochin lymfaa', Päivälehti 30 December 1890, 3.

${ }^{104}$ Undated notes [January 1891] by Hilda Asp.

${ }^{105}$ Hanna Asp to HE 9 January 1891; HA to family 1 January 1891; Gradmann, op.cit. (note 7), 101.

${ }^{106}$ HA to family 15 January 1891; Niiniluoto, op. cit. (note 3) 245-8; Huhtala op. cit. (note 19).

${ }^{107}$ 'Lymfattu', op. cit. (note 65) 4 March 1891, 3.

${ }^{108}$ 'Lymfattu', op. cit. (note 65) 26 March 1891, 3.
} 


\section{Conclusion}

The investigation has been structured around the notion of 'coping methods'. One benefit in using such a general, non-technical concept is that it does not, from the outset, differentiate between medical and lay conceptions, or rational and 'alternative' therapies, and can therefore be applied in widely different historical and cultural contexts. Nor does it restrict the inquiry on either conceptual or on practical tools, although I have separated the two for heuristic purposes.

Conceptualisation - whatever its specific form - is a fundamental way of controlling the threat of disease and also a prerequisite for communicating the experience to others. The term 'conceptual coping methods' has been used here to refer to the naming, classificatory, explanatory and narrative practices that people use in making sense of illness. Engaging in such practices, people draw both from their personal beliefs and experiences and from shared cultural resources (including scientific knowledge). I have used the term 'script' to refer to interpretative patterns that are relatively well-established and widespread in a certain cultural context but lack the coherence and scientific authority of theories. Late nineteenth-century people who wanted to make sense of phthisis/consumption/pulmonary tuberculosis could draw on a variety of scripts. Hilda Asp was more likely to interpret pathological phenomena in terms derived from mainstream medicine than the Erkko brothers, who were more attracted to naturopathic notions like 'regrounding' and 'crises'. In conceptualising their ill health, Elias and Henrik Erkko also made heavy use of 'the nerve script' that revolved around the notion of diffential nervous power and also incorporated the shape-shifting 'hereditary taint'. Henrik and Hilda eventually also drew from the bacteriological script and acted accordingly, having themselves injected with tuberculin. When Henrik Erkko discussed the loss of his brother in his published texts, he drew from the romanticsentimentalist script, which has otherwise been relatively marginal in Finnish representations of tuberculosis.

Like many letter-writers at the time, Hilda Asp and Elias and Henrik Erkko were highly preoccupied with their health. The Asp-Erkko correspondence has been particularly useful for my purposes, thanks to the exceptionally detailed, articulate and open manner in which they, and especially Elias Erkko, discussed their ill health. Erkko's sophisticated disease conception reminds us that lay conceptions of disease can be complex. His etiological model distinguished between predisposing and exciting causes, as well as between primary and secondary manifestations. In terms of structure, the model did not essentially differ from contemporanous medical thinking. The majority of practitioners still explained tuberculosis in terms of multiple predisposing and exciting causes and were more likely to refer it back to heredity than to contagion. ${ }^{109}$ Elias's choice of the main predisposing factor (weak nerves) and the main aggravating factor (masturbation) were not fully in line with medical thinking about tuberculosis, but neither were they wholly idiosyncratic, drawing as they did from the open-access repository of widely available cultural and semantic resources. Although his etiological model was fundamentally flawed and in some respects utterly unhelpful, it did leave room for hope and individual agency. Healthy life choices could compensate for the weak nerves, and, as the term 'genital immaturity' indicates, masturbation was something that might well one day be left behind. Indeed, one reason for Elias Erkko's critical view of mainstream tuberculosis medicine, as epitomised by Görbersdorf Sanatorium, was his wish to retain full agency and to reject the role of the patient.

The term 'practical coping methods', as employed in this paper, covers the tangible means that people use to prevent, alleviate or cure diseases. Late nineteenth-century consumptives who navigated the transnational medical market in search for an effective cure were faced with a bewildering array of treatment choices with divergent historical roots. The Erkko-Asp letters contain references to home remedies rooted in Finnish folk traditions, dietetic-hygienic prescriptions coinciding with Galenic principles; humoural, constitutional and symptomatic remedies prescribed by regular physicians; German

\footnotetext{
${ }^{109}$ Worboys, 'From Heredity' op. cit. (note 8), 81, 91-2; Worboys, 'The Sanatorium', op. cit. (note 8), 49-50; Smith, op. cit. (note 8), 36-8, 47-9.
} 
natural healing and tuberculin, a specific (albeit defective) medicine designed to eliminate tuberculosis bacteria. Even a psychic was consulted for a posthumous evaluation of treatment choices. Age-old beliefs mingled with state-of-the art medical beliefs and avant-garde practices, and school medicine rubbed shoulders with folk and irregular healing. This did not always happen without dissonance. Such dissonance could be a source of added suffering, as when the ailing Elias navigated between regular medicine and natural healing, or when Hilda tried to nurse him back to health at the crossfire of contradicting medical advice. Living in what has been called 'the age of new medical pluralism', we have no difficulty in recognising the tensions that accompany extensive freedom of choice.

Funding. The research was funded by the Academy of Finland, grant no. 259547. 